\title{
KECERDASAN SOSIAL PADA REMAJA KPOPERS MINANG DITINJAU DARI PERENTAL BONDING
}

\section{SOCIAL INTELLEGENCE IN YOUTH KPOPERS IN MINANG ASSESSED FROM PERENTAL BONDING}

\author{
${ }^{1}$ Vira Yuliani, ${ }^{2}$ Rida Yanna Primanita \\ ${ }^{1,2}$ Jurusan Psikologi, Fakultas Ilmu Pendidikan, Universitas Negeri Padang \\ e-mail: vira.yuliani.17@gmail.com
}

\begin{abstract}
Introduction Adolescent age makes adolescent development tasks increase, one of which is involved in social structures. The existence of group formation in adolescents is likely to influence the social attitudes of these adolescent. This study aims to see the differences in the level of adolescent social intellegence in terms of parental bonding (parent-child bonding).
\end{abstract}

Method The subjects of this study were 38 kpopers from the Minang tribe who lived in West Sumatera, with an age range of 12-20 years. The sample was taken by using a purposive random sampling technique, with a Likert-type questionnaire. The data analysis technique used in this research is the one way ANOVA statistical technique.

Results of this study indicate that there are differences in the social intellegence of Minang kpopers adolescents in terms of parental bonding, with a p-value of 0.025 ( $p<0.05)$. with 12 subjects in the optional parenting parental bonding type, 6 subjects in the affectionaned control parental bonding category, 13 subjects in the affectionated constrait category, and 7 subjects in the neglected parenting category.

Conclusions and Recommendation There are differences in the social intellegence of Minang Kpopers adolescents in parental bonding. This research that recommendation for research to correlation all type of parental bonding with social intellegence.

Keywords: Parental bondiing, social intelligence, adolescent, Minang, kpopers.

\begin{abstract}
ABSTRAK
Pendahuluan Usia remaja membuat tugas-tugas perkembangan remaja semakin bertambah, salah satunya keterlibatan di dalam struktur sosial. Adanya pembentukan kelompok pada remaja berkemungkinan memengaruhi sikap sosial remaja tersebut. Penelitian ini bertujuan untuk melihat perbedaan tingkat kecerdasan sosial remaja ditinjau dari parental bonding (ikatan orangtua dan anak).

Metode Subjek penelitian ini adalah remaja kpopers dari Suku Minang yang berdomisili di Sumatera Barat berjumlah 38 orang dengan rentang usia 12-20 tahun, pengambilan sampel penelitian ini menggunakan teknik purposive random sampling, dengan kuesioner tipe likert. Teknik analisis data yang digunakan dalam penelitian ini adalah teknik statistik one way anova.

Hasil penelitian ini menunjukkan adanya perbedaan kecerdasan sosial remaja Minang kpopers ditinjau dari parental bonding, dengan nilai p $0.025(\mathrm{p}<0.05)$. dengan 12 subjek pada tipe parental bonding optional parenting, 6 subjek pada kategori parental bonding affectionated control, 13 subjek pada kategori affectionated constrait, dan 7 subjek pada kategori neglected parenting.
\end{abstract}


Kesimpulan dan Saran Adanya perbedaan tingkat kecerdasan sosial remaja Minang Kpopers berdasarkan parental bonding. Penelitian ini merekomendasikan untuk meneliti hubungan setiap tipe parental bonding dengan kecerdasan sosial.

Kata kunci: Parental bonding, kecerdasan sosial, remaja, Minang, kpopers.

\section{Pendahuluan}

Remaja merupakan tahap perkembangan yang juga dikenal sebagai masa pubertas yang menjadi masa transisi anak-anak ke masa dewasa, tahap ini juga menjadi fase awal pembentukan identitas diri dan kepribadian. Fase ini dimulai sekitar umur 11 atau 12 tahun dan pada umumnya berakhir saat umur 20 tahun. (Papalia, 2008). Remaja sudah mengeksplorasi lingkungan sosialnya sejak berada pada fase awal. (Hurlock, 1980). Fase ini membuat tugas-tugas remaja sebagai individu di lingkungan sosial bertambah, remaja dituntut untuk mampu menjalin hubungan dengan teman sebaya dan menjalankan peran yang sesuai dengan jenis kelamin mereka di lingkungan sosial. (Ardi, Ibrahim, \& Said, 2012). Remaja juga memiliki dorongan untuk melepaskan diri dari keterikatan pada keluarga, dan mengalihkan ketertarikan pada lingkungan sosial.

Teman sebaya menjadi salah satu pusat interaksi sosial remaja, pembentukan kelompok remaja dengan hobi yang sama mengakibatkan adanya kesamaan perilaku antar anggota kelompok, seperti kpopers adalah salah satunya, kpopers merupakan sebutan untuk penggemar gelombang hallyu (Korea) baik musik, drama, dan budaya Korea. Studi membuktikan hubungan anggota dalam komunitas ini memengaruhi perilaku sosial mereka. Seperti memahami emosi sendiri, emosi orang lain dan kemampuan menempatkan diri secara sosial. (Lyanti, 2019).

Tingkat pencapaian tugas remaja secara sosial berbeda pada setiap individu. Peran orangtua dan lingkungan yang baik, dalam proses mendampingi remaja akan menghasilkan kematangan dan kecerdasan sosial yang baik pula. (Umami, 2019). Kecerdasan sosial merupakan kemampuan dan pengetahuan yang dimiliki oleh individu dalam memahami, mengelola, menempatkan diri dan bertindak bijak pada situasi sosial. (Erikson, 1980).

Remaja yang memiliki kecerdasan sosial yang baik mampu untuk memahami perasaan orang lain, mampu menjalin hubungan baik dengan orang lain, mampu mengatur dan menempatkan diri di lingkungan sosial, serta mampu memecahkan masalah yang mungkin muncul di lingkungan sosialnya. (Goleman, 2006). Selain itu remaja dengan kecerdasan sosial yang baik juga dapat menekan prilaku agresi dan kesepian pada usia remaja. Sebaliknya remaja dengan kesepian sosial yang tinggi memiliki resiko menjadi korban bullying. (Isnani, 2019., Acquah.,et all, 2015). Kecerdasan sosial dipengaruhi oleh beberapa faktor, salah satunya adalah ikatan dengan orangtua (parental bonding). (Mitsopoulou \& Giovazolias, 2013).

Parental bonding adalah ikatan emosional dan psikologis yang terbentuk antara orangtua dan anak, yang dipengaruhi oleh karakteristik anak dan karakteristik orangtua atau sistem pengasuhan. Ikatan yang terbentuk berupa hubungan timbal balik dan dinamis. Bonding yang baik ditandai dengan kehangatan, keterbukaan, kepedulian, dan pengawasan yang baik dari orangtua terhadap remaja. (Parker, Tupling, \& Brown, 1979). Remaja yang tidak mendapatkan kasih sayang, pengawasan, dan kehangatan dari orangtua akan memiliki perilaku sosial yang menyimpang seperti, bolos sekolah, merokok, terlibat pertengkaran antar remaja, dan seks bebas. Perilaku di atas tidak menggambarkan kecerdasan sosial yang baik, seperti kriteria yang sudah diuraikan. (Apriani \& Sugihen, 2017).

Fenomena yang diperoleh dari hasil wawancara terhadap dua orang remaja 
kpopers menunjukkan data yang berbeda terkait ikatan dengan orangtua dan perilaku sosial mereka. S1 mengaku sangat dekat dengan orangtuanya, hal ini ditunjukkan dengan selalu berbagi rahasia pribadi, menunjukkan kasih sayang secara nonverbal seperti memeluk dan tersenyum saat bercerita, S1 mengaku kalau orangtuanya mengizinkan dia melakukan apapun yang dia sukai.

S2 mengaku tidak dekat dengan orangtuanya, terutama ayah. S2 tidak menceritakan apapun mengenai hal pribadi pada ayahnya, menurut S2 ayah dan ibunya tidak menunjukkan kasih sayang secara nonverbal, tidak memeluk, tersenyum dan mendengarkan saat dia ingin bercerita. S2 merasa ayah dan ibunya membebaskan dia melakukan apapun yang diinginkan dan ayahnya tidak pernah memberi perhatian ataupun peduli padanya. Perilaku sosial S1 dan S2 juga menunjukkan perbedaan, S1 mengaku kalau dia akan mendengarkan masalah teman-temannya dan bisa merasakan perasaan subjektif yang dirasakan temannya, dia akan menolong dengan senang hati orang yang membutuhkan baik yang dikenal maupun tidak. S2 mengaku kalau ia tidak tertarik mendengarkan masalah orang lain karena menurutnya tidak ada yang akan mendengarkan masalahnya, dia juga tidak berniat menolong orang yang tidak dikenal, namun S2 memberikan kemungkinan menolong jika orang tersebut ada di satu komunitas/ kelompok yang sama dengannya.

Fenomena tersebut membuat peneliti tertarik untuk meneliti mengenai kecerdasan sosial pada remaja kpopers di tinjau dari parental bonding karena, adanya perbedaan parental bonding pada subjek wawancara menghasilkan perilaku sosial yang berbeda. Minimnya penelitian tentang kaitan kecerdasan sosial dan parental bonding berbanding terbalik dengan penelitian tentang kaitan pola asuh dengan kecerdasan sosial, sedangkan menurut teori parental bonding terbentuk sebelum pola asuh. Hal ini membuat penelitian ini penting untuk dilakukan. (Pratiwi \& Rustika, 2017.; Robiyah, Ekasari, \& Witarsa, 2018).

Penelitian ini dilakukan pada remaja keturunan Minang yang berdomisili di Sumatera Barat, budaya Minang merupakan salah satu budaya yang unik di indonesia, budaya yang mengangkat filosofi "adat basandi sarak, sarak basandi kitabullah" ini mempunyai kebiasaan gotong royong dalam berinteraksi dengan sesama. Individu yang tumbuh dengan budaya Minang dikenal lantang dalam komunikasi, terbuka dan demokratis. (Asysura \& Rizal, 2020). Remaja yang besar dengan budaya Minang juga memegang nilai-nilai budaya "dima bumi dipijak sinan langik di junjuang" yang mengharuskan remaja Minang mudah bergaul dalam lingkungan sosial yang menjadi tempat remaja tersebut tinggal. (Siregar, \& Kustanti, 2018). Berdasarkan uraian di atas, peneliti tertarik untuk meneliti tentang kercerdasan sosial remaja Minang kpopers ditinjau dari parental bonding.

\section{Metode}

$\begin{array}{ccr}\text { Penelitian } & \text { ini menggunakan } \\ \text { pendekatan } & \text { kuantitatif } & \text { dengan }\end{array}$ membedakan data dalam dua kelompok, data parental bonding dan data kecerdasan sosial. Definisi operasional parental bonding merupakan perilaku kehangatan dan kontrol yang seimbang yang ditunjukkan oleh orangtua pada anak.

Definisi operasional kecerdasan sosial remaja adalah kemampuan remaja dalam bertindak di lingkungan sosial dengan memperhatikan pembawaan diri, empati, dan kognisi sosial.

Populasi penelitian ini adalah remaja Minang penggemar kpop yang berada pada kelompok usia 12-20 tahun dan berdomisili di Sumatera Barat. Sampel penelitian ini berjumlah 38 orang yang tersebar di daerah berbeda di Sumatera Barat.

Teknik pengambilan sampel yang digunakan dalam penelitian ini adalah purposive random sampling. Teknik 
pengambilan data penelitian ini menggunakan kuesioner tipe likert dengan empat pilihan jawaban yaitu SS (sangat setuju), S (setuju), TS (tidak setuju), STS (sangat tidak setuju). Instrument penelitian ini merupakan skala parental bonding yang diadaptasi dari skala PBI milik Parker, Tupling, \& Brown tahun 1997 yang terdiri dari dua aspek yaitu care dan protection dan sepuluh item yang sudah diuji coba untuk budaya Minang dan skala kecerdasan sosial yang terdiri dari 2 aspek yaitu kesadaran sosial dan fasilitas sosial yang sudah di uji validitas dan reliabilitasnya.

Hasil uji reliabilitas skala kecerdasan sosial 0,669, maka skala kecerdasan sosial dinyatakan reliabel. Hasil uji reliabilitas untuk skala parental bonding 0,678 , maka skala parental bonding reliabel.

Analisis statistik yang digunakan dalam penelitian ini adalah statistik parametrik dengan teknik analisis data anava satu jalur. Anava satu jalur merupakan teknik analisis untuk 3 kelompok data interval atau rasio yang berasal dari 1 variabel bebas (Winarsunu, 2009).

\section{Hasil dan Pembahasan Hasil}

Subjek penelitian ini merupakan remaja kpopers atau penggemar musik dan drama Korea yang mempunyai ayah dan ibu suku Minang. Subjek berjumlah 38 orang, berusia 12-18 tahun dan berdomisili di Sumatera Barat.

Tabel 1: Pengkategorian skor subjek pada skala parental bonding

\begin{tabular}{llll} 
Aspek & Skor & \multicolumn{2}{c}{ Subjek (\%) } \\
\hline Care & & & \\
\hline Tinggi & $15 \leq \mathrm{X}$ & 26 & $68,4 \%$ \\
\hline Rendah & $\leq \mathrm{X} 10$ & 12 & $31,5 \%$ \\
\hline \multirow{2}{*}{ Protection } & jumlah & 38 & \\
\cline { 2 - 4 } & & &
\end{tabular}

\begin{tabular}{llll}
\hline Tinggi & $15 \leq \mathrm{X}$ & 21 & $55,2 \%$ \\
\hline Rendah & $\leq \mathrm{X} 10$ & 17 & $44,7 \%$ \\
\hline & Jumlah & 38 & $100 \%$ \\
\cline { 2 - 4 } & &
\end{tabular}

Skor kategorisasi parental bonding di atas menunjukkan bahwa dari 38 remaja Minang kpopers yang menjadi subjek penelitian, 26 orang di antaranya atau sekitar $68,4 \%$ sampel memiliki skor care yang tinggi dan 12 orang remaja atau sekitar 31,5\% dari sampel memiliki skor care yang rendah. Sedangkan, pada skor protection dari 38 remaja Minang kpopers yang menjadi subjek penelitian 21 orang $(55,2 \%)$ diantaranya mempunyai skor protection yang tinggi dan 17 orang $(44,7 \%)$ mempunyai skor protection rendah. Berdasarkan 4 tipe parental bonding, 12 orang remaja Minang kpopers memenuhi kriteria optional parenting (care> protection), 6 orang remaja Minang kpopers memenuhi kriteria Affectionated control (care < protection), 13 orang remaja Minang kpopers memenuhi kriteria affectionated constrait (skor care \& protection sama sama tinggi) dan 7 orang remaja Minang kpopers masuk ke dalam neglected parenting (skor care \& protection sama sama rendah).

Tabel 2: Pengkategorisasian skor subjek skala kecerdasan sosial

\begin{tabular}{llll}
\hline Kategori & Skor & \multicolumn{2}{l}{ Subjek (\%) } \\
\hline & & $\mathrm{F}$ & $\%$ \\
\hline Tinggi & $54 \leq \mathrm{X}$ & 8 & $21 \%$ \\
Sedang & $37,5 \leq+$ & 30 & 78,9 \\
& 55,5 & & $\%$ \\
\hline Rendah & $\leq \mathrm{X} 36$ & 0 & \\
\hline & Jumlah & 38 & $100 \%$ \\
\hline
\end{tabular}

Berdasarkan skor kategori kecerdasan sosial di atas, dari 38 orang remaja Minang kpopers yang menjadi subjek penelitian 8 orang memenuhi kriteria kecerdasan sosial tinggi dan 30 orang berada pada kategori sedang dan tidak ada yang berada pada kategori rendah. Hasil uji normalitas data parental bonding \& kecerdasan sosial menggunakan kolgomorov smirnov KS-Z, sebesar 0.816 dengan nilai $\mathrm{p} 0.518(\mathrm{p}>0.05)$ maka dapat disimpulkan bahwa data parental bonding dan kecerdasan sosial berdistribusi normal. Hasil uji homogenitas dari variabel parental bonding dan kecerdasan sosial dengan hasil 
0.851 ( $\mathrm{p}>0.05$ ), maka dapat disimpulkan bahwa data variabel parental bonding dan kecerdasan sosial homogen. Hasil uji hipotesis menggunakan teknik statistik one way anova didapatkan nilai $\mathrm{F} 3.539$ dan nilai signifikansi $0.25 \quad(\mathrm{p}<0.05)$ hal ini menunjukkan ada perbedaan kecerdasan sosial remaja Minang kpopers ditinjau dari parental bonding.

\section{Pembahasan}

Hasil penelitian menunjukkan bahwa terdapat perbedaan kecerdasan sosial remaja Minang kpopers ditinjau dari parental bonding. Selanjutnya, dari perhitungan skor empirik subjek ditemukan bahwa remaja kpopers Minang di Sumatera Barat kebanyakan memiliki tipe parental bonding affectionated constarit (care \& protection sama sama tinggi). Kemudian, untuk perhitungan skor kecerdasan sosial remaja Minang kpopers kebanyakan remaja berada pada kategori sedang hingga tinggi.

Perhitungan skor perkategori parental bonding remaja Minang kpopers didapatkan hasil 12 remaja Minang kpopers berada pada kategori optional parenting (care> protection), hal ini menunjukkan jika remaja yang berada pada kategori ini mempunyai orangtua yang menunjukkan kehangatan, kepedulian dan perhatian pada mereka. Namun, tetap memonitor, mengontrol dan menghargai aspirasi dan pilihan remaja dengan baik. Remaja yang berada pada kategori ini mendapatkan ratarata skor kecerdasan sosial sedang, hal ini menunjukkan bahwa remaja cukup mampu untuk mengembangkan empati, menjaga komunikasi dengan lingkungan sosialnya, memahami kode sosial, terlibat dalam pemecahan masalah sosial, dan menempatkan diri dengan baik di lingkungan sosial.

Selanjutnya, pada tipe parental bonding affectionated control (care<protection) terdapat 6 orang remaja kpopers Minang. Remaja yang berada pada tipe parental bonding ini memiliki orangtua yang kurang peduli pada remaja namun, tidak membebaskan remaja memilih tanpa mempertimbangkan kebutuhan. Untuk skor kecerdasan sosial remaja Minang kpopers pada kategori parental bonding ini memiliki skor sedang hingga tinggi. Remaja dengan kecerdasan sosial tinggi akan sangat mampu mengembangkan perilaku yang mengindikasikan kecerdasan sosial seperti, memahami sinyal nonverbal, komunikasi yang baik dengan lingkungan sosial, memahami perasaan orang lain, memahami kode sosial, persentasi diri yang autentic dan memberikan kesan diri di lingkungan sosial.

Pada tipe parental bonding ketiga yaitu affectionate constrait (care \& protection sama sama tinggi), terdapat 13 remaja kpopers Minang. Remaja Minang kpopers yang berada pada tipe parental bonding ini memiliki orangtua yang kaku dan mengendalikan remaja. Skor kecerdasan sosial remaja yang berada pada kategori ini sama seperti sebelumnya, dimana remaja Minang kpopers berada pada rentang skor sedang hingga tinggi.

Tipe parental bonding keempat neglectful parenting (care \& protection sama sama rendah) terdapat 7 orang remaja Minang kpopers. Remaja pada tipe parental bonding ini memiliki orangtua yang menunjukkan perilaku tidak peduli dan membebaskan remaja bertindak sesuka hati mereka. Skor kecerdasan sosial remaja Minang kpopers pada tipe ini berada pada kategori sedang hingga rendah, hal ini berarti remaja tidak mampu untuk menunjukkan perilaku-perilaku yang menggambarkan kecerdasan sosial seperti mengembangkan empati, memahami kode sosial, menciptakan kesan diri yang autentic dan menempatkan diri dengan baik di lingkungan sosial.

Penjelasan indikator perilaku di atas sejalan dengan hasil penelitian sebelumnya bahwa remaja laki-laki dan perempuan yang memiliki care yang tinggi dengan ibu mereka akan mengembangkan sikap mengerti perasaan orang lain dan mengerti kesedihan orang lain. Remaja dengan care yang baik juga akan mendukung rendahnya 
perilaku bullying dikalangan remaja. (Mitsopoulou \& Giovazolias, 2013).

Selanjutnya, remaja yang berada pada skor kecerdasan sosial yang baik, akan mampu mengerti perasaan orang lain, menunjukkan empati, kemampuan membawa dan menempatkan diri di sosial dengan baik, menjadi autentich, dan menunjukkan kesan berpengaruh di sosial. (Soejanto \& Soekarman, 2015).

Sebaliknya, remaja dengan kecerdasan sosial yang rendah akan rentan terhadap berbagai masalah sosial, seperti rendahnya resilience remaja dan memengaruhi hasil belajar pada remaja. (Andiani \& Listiyandini, 2017., Manullang, 2015).

Penelitian sebelumnya juga membuktikan jika keterlibatan orangtua pada perkembangan sosial remaja membantu remaja mengembangkan sikap empati afektif yang membantu mengurangi perilaku perundungan di sekolah, semakin tinggi keterlibatan orangtua terhadap keseharian remaja, maka semakin baik empati afektif itu berkembang. (Rizkyanti \& Murty 2018). Kedekatan orangtua dan remaja juga memengaruhi hubungan pertemanan yang berkembang pada remaja, kedekatan yang positif searah dengan terbentuknya pola hubungan positif pertemanan antar remaja. (Sya'diah, 2018).

Parental bonding juga akan memengaruhi penyesuaian diri remaja di sekolah, bonding antara anak dan orangtua akan membantu penyesuaian diri remaja di lingkungan dan membantu remaja untuk mengembangkan juga kecerdasan emosionalnya. (Sultan, Rafiq, \& Kanwal, 2019).

Selain parental bonding, ada beberapa faktor yang juga mendukung berkembangnya kecerdasan sosial yang baik. Pola asuh yang dipilih oleh orangtua juga berpengaruh pada pembentukan kecerdasan sosial pada remaja, pola asuh demokratis minsalnya, berpengaruh positif pada pembentukan kecerdasan sosial remaja. (Robbyah, Ekasari, \& Witarsa, 2018). Kelekatan (attachment) juga menjadi salah satu faktor yang mendukung berkembangnya kecerdasan sosial remaja, remaja yang memiliki kelekatan yang baik dengan orangtua mereka akan mengembangkan kemampuan sosial yang sportif dalam masyarakat. (Gorbanian, Mohammadloo, \& Fatemeh, 2016).

\section{Kesimpulan}

1. Pada penelitian ini ditemukan perbedaan tingkat kecerdasan sosial remaja Minang kpopers ditinjau dari parental bonding.

2. Tipe parental bonding remaja Minang kpopers di Sumatera Barat adalah afectionated constrait (care \& protection sama sama tinggi).

3. Tingkat kecerdasan sosial remaja Minang kpopers di Sumatera Barat sedang hingga tinggi.

\section{Saran}

1. Peneliti selanjutnya agar mengkaji lebih dalam hubungan setiap tipe parental bonding dengan kecerdasan sosial.

2. Peneliti selanjutnya agar mengkaji tentang parental bonding dan kecerdasan sosial di berbagai budaya.

3. Peneliti selanjutnya dapat langsung melakukan pengambilan data ke lapangan, tidak menggunakan google form.

\section{Daftar Pusataka}

Ardi, Z., Ibrahim, Y., \& Zaid, A. 2012. Capaian tugas perkembangan sosial siswa dengan kelompok teman sebaya dan implikasinya terhadap program pelayanan bimbingan dan konseling. Jurnal konselor. 01,(1). 1-8. ISSN: 1412-9760.

Apriani, N., \& Sugihen, B. (2017). Perkembangan sosial remaja pada keluarga yang bercerai (studi kasus tentang perilkau sosial remaja dari keluarga yang bercerai di kampung takegon barat kecamatan lut tawar, kabupaten aceh tengah). Jurnal ilmiah mahasiswa FISIP unsyiah. 02,(4). 1-13. retreived from www.jim.unsyiah.ac.id/FISIP. 
Andriani, A., \& Listyandini, R. (2017). Peran kecerdasan sosial terhadap resiliensi pada mahasiswa tingkat awal. Jurnal ilmiah psikologi. 4, (1). 67-90. Retreived from: journal.uinsgd.ac.id.

Asysyura, S., \& Rizal, G. (2020). Perbedaan asertivitas remaja minang ditinjau dari pola asuh orangtua. Proyeksi. 15,(2). 120-130. ISSN: 2656-4173.

Acquah, E., Topalli, P., Wilson, M., Junttila, N., \& Niemi, P. (2015). Adolescent loneliness and social anxienty as predictors of bullying victimisation. International journal of adolescent and youth. 21,(3). 320-311. doi: $10.1080 / 02673843.2015 .1083449$.

Erikson, E. (1980). identity and the life cycle. New york : Norton.

Ghorbanian, E., Mohammadloo, H., \& Fatemeh, M. (2016). Attachment Style and social skill of children: The function of mediator emotional intellegence. Community healty. 3,(4). 278-288. Retreived from: journals.sbmu.ac.ir.

Goleman, D. (2006). The socially intelegent. Educational leadership. 64,(1). 76-81. Retreived from: cmapspublic2.ihmc.us.

Gravin. (2017). Hubungan kecerdasan sosial dengan kesepian pada remaja. Jurnal muara ilmu sosial humaniora dan seni. 1, (2). 93-99. ISSN-L 25796356.

Pratiwi, K.., \& Rustika, M. (2017). Peran pola asuh autoritatif dan konsep diri terhadap kecerdasan sosial remaja awal sekolah menengah pertama negeri denpasar. Jurnal psikologi udayana. 04,(2). 448-459. ISSN: 23545607.

Hurlock, E. (1980). Psikologi perkembangan: Suatu pendekatan sepanjang rentang kehidupan. Jakarta: Gramedia.

Lyanti, R. (2019). Pengaruh konformitas, self control dan kecerdasan emosi terhadap agresivitas pada penggemar kpop/kpopers. Skripsi. Universitas islam negeri syarif hidayatullah.

Mitsopoulou, E., \& Giovazolias, T. (2013). The relationship between perceived parental bonding and bullying: The mediating role of empathy. The european jurnal of counselling $\begin{array}{lll}\text { psychology. } & 2,(1) . & \text { doi: }\end{array}$ 10.5964/ejcop.v2i1.2.

Manullang, R. (2015). Pengaruh kecerdasan sosial terhadap prestasi belajar siswa Di SMK negeri 2 kota Jambi. Jurnal ilmiah universitas batang hari jambi. 15,(03).19-22. Retreived from:

Ji.ubari.ac.id.

Parker, G., Tuppling, H., \& Brown, B. (1979). A parental bonding instrument. British journal of medical psychology. 52. 1-10. Retreived from: Willeyonelibrary.com.

Papalia,D., dkk. (2008) . Psikologi perkembangan. Jakarta:kencana

Winarsunu, T. (2009). Statistik dalam penelitian psikologi dan pendidikan. Malang: UMM.

Robiyah, R., Ekasari, D., \& Witarsa, R. (2018). Pengaruh pola asuh ibu teradap kecerdasan sosial anak usia dini di TK Kenanga Kabupaten Bandung Barat. Jurnal obsesi: Jurnal pendidikan anak usia dini. 2,(1). 7481. ISSN: 25498956.

Sultan, S., Rafiq, S., \& Kanwal, S. (2019). Parental bonding and social adjusment: Evidence from the mediation by emotional intellegence. Journal of social sciences. 2,(02). 3245. Retreived from: Uwjjs.org.pk.

Rizkyanti, C., \& Murty, A. (2018). Empathy in early childhood: A 
pleminary study. Humanisma:

Journal of gender studies. 2,(2). 138-

145. doi:/10.30983/jh.v2i2.813.

Siregar, A., \& Kustanti, S. (2018).

Hubungan antara gegar budaya

dengan penyesuaian diri pada

mahasiswa bersuku minang di

Universitas Diponegoro. Jurnal

empati. 7,(2). 48-65. Retrieved from: ejurnal3.undip.ac.id.

Soejanto, L., \& Soekarman, F. (2015). Tingkat kecerdasan sosial mahasiswa fakultas keguruan dan ilmu pendidikan universitas kanjuruhan malang. Jurnal konseling indonesia.
$1,(1)$.
14-22.doi:

/10.21067/jki.v1i1.852.

Sya'diah, C. (2018). Hubungan antara pola parental attachment dengan friendship quality pada remaja awal. Skripsi. Universitas negeri sunan ampel.

Umami, I. (2019). Promoting character social and morals trough islamic educational values. Skirpsi. Institut agama islam negeri metro. 